\title{
Flor Silvestre (1943) de Emilio Fernández
}

\section{Karina Pineda}

La palabra Revolución es el intento de cambiar la manera en la cual una sociedad es gobernada junto con la economía y la cultura de algún lugar. Algunas de las causas por las cuales ha habido revoluciones como en México o en otros países ha sido por problemas económicos y falta de dinero. También puede que estén pasando por problemas de clase social entre los ricos y los pobres, debatiendo quién debe tener el poder, pero también pueden estar peleando por religión y cuál es la religión que se debe de establecer, y eso es lo que estaba pasando en México durante la Revolución, lo cual derivó en el tema de la Revolución mexicana.

Una película que hemos visto durante esta clase y que muestra algunos aspectos que marca la Revolución mexicana ha sido la película Flor Silvestre. Esta película fue dirigida por Emilio Fernández y algunos de los protagonistas fueron Dolores del Río y Pedro Armendáriz, personajes muy famosos durante la época de la posrevolución. Ellos han salido en muchas películas durante ese tiempo. Dolores del Río en esta película caracteriza a Esperanza, quien se muestra como una mujer sumisa a su marido; ella es una mujer bonita y la muestran como una mujer que sufre primero por su familia y luego por la muerte de su esposo.

Uno de los temas y el enfoque principal de la película Flor Silvestre es la desigualdad de las clases sociales, es decir, por qué hay ricos y pobres. La situación de los de clase baja, que no tienen muchos recursos y en muchos de los casos son los que trabajan para los ricos. Esta desigualdad de clase sociales es uno de los temas principales de la Revolución mexicana: luchar por la igualdad entre ellos.

En la película se trata el tema de clases porque José Luis, el hijo de una familia rica, se casa con Esperanza, una muchacha campesina que viene de una familia muy humilde a diferencia de José Luis, cuya familia tiene alto prestigio. Durante la película, cuando el abuelo de Esperanza se entera de que el joven José Luis se la ha robado, va a su casa a buscarlo y habla con la madre de él, pero durante esa escena se muestra la diferencia y la desigualdad, ya que él está en sus rodillas y la mamá lo mira hacia abajo ya que él es menos que ella porque ellos pertenecen a una familia de gran prestigio. Esperanza para su abuelo es su adoración y la quiere mucho, se menciona cómo su abuelo la llama Flor Silvestre, lo cual es una flor que nace en al campo y nace en tierras de indígenas; esto lo hace ver que Esperanza es una mujer humilde, de baja clase social y menos que José Luis. El papá de José Luis se entera de que él está con los revolucionarios y de que se casó con Esperanza y lo echa de la casa también porque él tiene una mentalidad diferente a la de su padre. Al padre de José Luis lo matan unos hombres, y él va a buscar venganza. Entonces unos hombres van y se 
llevan a Esperanza y su hijo, y asesinan a José Luis. Al final, la película termina con Esperanza y su hijo, el cual ya está más grande y le está hablando sobre la tierra, y cómo su padre luchó por la igualdad de la tierra a través de la Revolución que ocurrió cuando su padre vivía, y así es como se logró la igualdad. Y al final la Revolución valió la pena ya que pudieron luchar en contra de la desigualdad, y se logró la justicia social. Y la lucha de dos tiempos, el pasado y el presente de un México moderno. Ya que tuvo que haber una Revolución para llegar a la igualdad entre pobres y ricos. El nombre de Esperanza de hecho enfatiza que hay esperanza para mejorar y su hijo simboliza el futuro lo cual va a ser mejor. Finalmente la Revolución sí valió la pena ya que México ha mejorado mucho desde los años cuarenta y cincuenta. El pelear sí valió la pena. 